\title{
The energy consumption of Paris and its supply areas from the eighteenth century to the present
}

\author{
Eunhye Kim · Sabine Barles
}

Received: 9 May 2011/Accepted: 18 December 2011/Published online: 15 January 2012

(C) The Author(s) 2012. This article is published with open access at Springerlink.com

\begin{abstract}
Since the eighteenth century and the industrial revolution, cities have experienced great changes in their metabolism, and particularly in their energy consumption: transitions from one energy source to another, growing per capita consumption, and total consumption to cite but a few. These changes also impact urban energy supply areas and supply distance. This paper estimates Paris's energy demand in both final and primary terms since the eighteenth century and gives an illustration of long-term socio-ecological interactions in an interdisciplinary perspective, connecting energy flow analysis, and historical research. It gives an overview of energy supply areas and assesses the distance between supply sites and the city. Paris's annual total energy requirement (TER) was about $19 \mathrm{GJ}$ per capita at the beginning of the eighteenth century and reached 30 GJ per capita in 1800; the supply area remained nearly the same with an average supply distance $\left(D_{\text {avg }}\right)$ of $200 \mathrm{~km}$. During the nineteenth century, Paris's population increased fivefold, and energy transitioned from biomass to fossil fuel. Per capita TER remained stable, whereas Paris's supply area moved progressively toward coal basins, in connection with the tremendous change in transport systems. As a consequence, the $D_{\text {avg }}$ grew to $270 \mathrm{~km}$ around 1870 . During the twentieth century, and especially since the Interwar period, per capita TER increased considerably (to $26 \mathrm{GJ} / \mathrm{cap} /$ year in 1910, $47 \mathrm{GJ} / \mathrm{cap} /$ year in 1946 and $126 \mathrm{GJ} / \mathrm{cap} /$ year in 2006). The internationalization of the energy supply and the shift to
\end{abstract}

E. Kim $(\varangle) \cdot$ S. Barles

Laboratoire Géographie-cités, UMR 8504, Institut de

Géographie, Université Paris I Panthéon Sorbonne,

191, rue Saint-Jacques, 75005 Paris, France

e-mail: enhye.kim@enpc.fr

S. Barles

e-mail: sabine.barles@univ-paris1.fr petroleum and natural gas also increased the remoteness of the supply sites: the $D_{\text {avg }}$ equaled $3850 \mathrm{~km}$ in 2006 .

Keywords Energy consumption - Energy supply area · Energy supply distance - Energy flow analysis .

Socio-ecological transition

\section{Introduction}

A society's direct and indirect resource consumption is central to sustainable development. A great deal of research has been conducted in the field of material and energy flow analysis, with certain studies examining the relationship between a society's metabolism and its land use (see for instance Weisz et al. 2006; Schandl and Schulz 2002). Considering urbanization as one of the major changes since the industrial era, analyzing and understanding urban metabolism and urban supply are of major importance.

Early urban metabolism studies focused on direct throughput of material and energy (Wolman 1965; Boyden et al. 1981; Duvigneaud 1980; Kennedy et al. 2007). Considering that most urban material and energy inputs are imported (instead of locally extracted), the question of imported natural resources and their related indirect flows is as relevant as to the one of direct flows. In the particular case of urban energy consumption, it depends on the energy source-renewable or fossil—and is related to the issue of primary versus final energy consumption. Recently, the issue of indirect ecological impacts related to society's mode of consumption has emerged as an important research question, particularly in the field of ecological economics (see Wiedmann 2008; Van Den Bergh and Verbruggen 1999; Hubacek and Giljum 2002 for embodied 
ecological footprint; Giljum et al. 2007 for embodied material flows in international trade). Furthermore, the energy supply impacts land in various ways and calls for a better characterization of urban environmental imprints (Barles 2010). Land as a resource can be consumed directly for biomass production (e.g., firewood) or for the various infrastructures and superstructures needed for extraction, transformation, and transportation (Smil 2008). Supply areas can be close to the city or remote, needing longer transportation and probably leading to greater environmental impacts.

Energy transitions and their consequences in terms of land use and environmental imprint also enter into the equation. From an ecological point of view, energy transitions are part of the long-term changes in the relationship between society and its natural resource (Sieferle 2001). They require historical insights to understand socio-natural trajectories (Fischer-Kowalski and Hüttler 1998). In 1980, the LTER (Long-Term Ecological Research) network was set up in the United States. The conceptualization of LTSER (Long-Term SocioEcological Research) was initiated in collaboration with many research institutes in Europe and in the United States to adopt a more interdisciplinary approach (Haberl et al. 2006; Fischer-Kowalski and Haberl 2007). Nevertheless, few long-term urban case studies exist and they rarely address the question of environmental imprints and energy transition-the study of Vienna's metabolism in terms of energy consumption and land use being an exception (Krausmann 2006).

This paper focuses on urban energy consumption and the area impacted by the city for its energy supply in the particular case of Paris during the last three centuries and follows a previous study dedicated to energy consumption accounting (Kim and Barles 2010). The food and material consumption of Paris has been reported with historical insights (Barles 2007, 2009a; Billen et al. 2009; Chatzimpiros 2011). Its historical energy consumption is less well known, except for several studies of various specific energy sources that generally do not consider environmental but rather socioeconomic issues (Larroque 1997; Beltran 2002; Williot 1999; Besnard 1942). This paper aims to provide empirical evidence on the French capital's energy regime(s), imprint(s), and transition(s) since the eighteenth century and to analyze them in terms of socio-natural interactions. It is based on an interdisciplinary approach, connecting historical to material and energy flow analyses.

The next section focuses on the methodological framework. Third section presents the case study and data sources. The quantitative results are presented with the indicators defined in fourth section. Section "Discussion" discusses the historical factors where key periods are identified on the basis of primary energy source changes in the quantitative results in the previous section, which influence the evolution of the energy supply system. The last section gives conclusions and research perspectives.

\section{Methods}

\section{Energy consumption}

To estimate energy consumption, the Material and Energy Flow Analysis (MEFA) framework (Fischer-Kowalski and Haberl 2007; Krausmann and Haberl 2002; Schandl and Schulz 2002) was applied to technical energy (not accounting for food imports, the subject of a future study). Since different energies have different qualities, the official method for equivalence and calorific value (UN 1982, 1987; IEA 2008) was used to quantify them. The result is expressed in gross calorific value and in joules according to the MEFA framework. Figure 1 presents the main flows under study.

Most of the literature dealing with energy consumption emphasizes two indicators: primary and final consumption. Whereas the definition of the latter is quite clear because it accounts for the energy delivered to the final consumers, primary consumption is more ambiguous. In official statistics for instance, it takes into account the total domestic consumption, including domestic losses, but does not consider the losses that are associated with imports (occurring outside the country under study): it thus underestimates the total energy consumption. The indicators derived from the MEFA framework overcome this problem by distinguishing (see also Fig. 1):

- total final energy consumption: TFEC = energy delivered to final consumer (often called "final consumption");

- direct energy input: DEI = domestic extraction + imports (where the flows of imports and exports do not

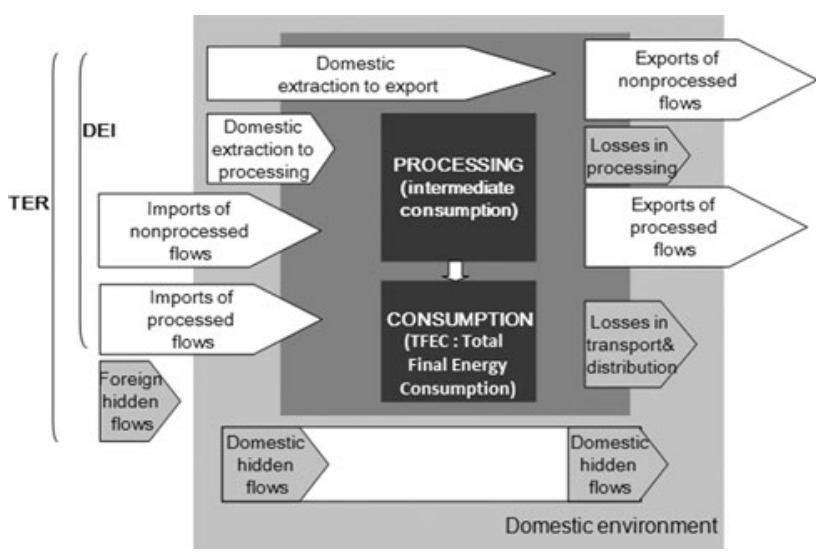

Fig. 1 Indicators derived from material and energy flow accounts (MEFA). Adapted from Matthews et al. (2000); Krausmann et al. (2004); Haberl (2001) 
include the energy losses that occur outside of the spatial boundary);

- $\quad$ domestic energy consumption: DEC $=$ DEI - exports (corresponding to total primary energy supply in official statistics);

- $\quad$ total energy requirement: TER $=$ DEI + domestic hidden flows + foreign hidden flows $=$ DEC + domestic hidden flows + foreign hidden flows + exports.

For this case study, data related to exports were not available for the entire period considered. It was assumed that Paris energy exports were not significant; it was therefore considered that DEC equals DEI. This assumption is confirmed by the historical analysis of the Paris energy supply and consumption. The stock accumulation and domestic hidden flows in extraction were considered zero for technical energy. Data availability varies for certain periods and energy sources under study. Conversion factors were used in order to determine the various indicators (see section "Data sources"). The comparison between DEC, TFEC, and TER shows the amount of energy loss inside the city (DEC - TFEC), outside the city (TER - DEC), and the total conversion losses (TER TFEC) (see section "Secondary energy and losses").

Energy supply area and distance

Paris's energy supply area-its energy imprint-was observed by energy group: firewood plus charcoal, solid mineral combustibles, crude oil and petroleum products, and natural gas. It was determined for four specific periods (see section "Data sources" and Fig. 6) and comprises four indicators: (1) the contribution of each source to Paris's energy consumption, significant to at least $0.5 \%$ level, (2) the proportion of different means of energy transportation, (3) the average supply distance $D_{\text {avg }}$ of each energy source expressed in kilometers, and (4) the maximum supply distance $D_{\max }$ of each energy source in kilometers. The origin is expressed at the département scale in France, except for hydraulic energy in 1965 and for all energy sources in 2006, which are expressed at the regional scale (at that time, national extraction was marginal), and at the national scale for foreign imports.

The contribution of each source supplying Paris from 1800 to 1965 was obtained from various data sources, which are detailed in section "Data sources". For 2006, the French Merchandise Transportation Information System, called SITRAM (2006), is available at the department scale. Available data estimate that $80 \%$ of the petroleum used was imported to Paris by pipelines connected to two different ports: Le Havre-Paris (in the Haute-Normandie region) and Donges (in the Pays-de-Loire region). The source of this petroleum was then considered as the same as the source of all the petroleum imported by sea to the corresponding regions. The source of the remaining 20\% was estimated using the SITRAM database, as for other energy sources. The extraction and exchange between European countries outside of the French territory was completed by statistical data from Eurostat (2008). Given that traffic data is expressed in tons, it was converted to energy terms using equivalence factors for each group of energy sources as the ton of coal equivalent for coal subproducts and the ton of oil equivalent for petroleum subproducts.

Most often, energy transportation from its extraction site to its consumption place is multimodal, and the distinction can be made between the first source of energy flow-the extraction site-and its last source-where the final part of its move to the city begins: logs were generally horsedrawn to river banks before being floated to Paris; natural gas and petroleum can sail for long distances before being transported by pipelines to their final destination. This paper only takes into account the main transportation mode in order to estimate the proportion of each means of transport. Therefore, for the nineteenth century, the mode considered was the transport from the last source to Paris: it was assumed that the last source was not significantly different from the first; for recent years, the transportation mode of energy sources such as natural gas and petroleum concerns the original source, i.e., the international and longest part of the route.

The distance from each French département and region to Paris was calculated directly, not taking into account the earth's deformation-assumed to be insignificant-less than $12 \%$ for the maximum supply distance of $690 \mathrm{~km}$, except for Corsica, with very few exports to Paris. The distance from each foreign country is orthodromic and based on each country's coordinates (CIA 2010).

Another important impact and imprint of energy supply concern secondary production. Indeed, secondary production generally needs transformation plants that greatly impact the landscape and the environment in urban areas. These technological facilities must then be taken into account when the urban energy imprint is analyzed and located. For the identification of this part of the energy imprint, another indicator was introduced: the proportion of secondary production according to its location (in \%).

\section{Historical analysis}

The quantification of energy consumption, energy imprint, and related indicators gives an overview of Paris's socioecological trajectory. However, these figures and pictures must be connected to the underlying historical processes in order to better understand whether or not these processes influence urban metabolism and how this may occur, one of the purposes of urban environmental history. 
Paris's energy supply and consumption has not yet been analyzed in such terms. This does not mean that the field is virgin: the history of technology, industrial and economic history, and urban history have been concerned by energy for decades. Some studies focus on a specific energy (see Williot 1999 for traditional manufactured gas; Beltran 2002 for electricity), the transportation system (Caron 1997), or the overall changes in the industrial and technical system (Woronoff 1998; Guillerme 2007). At the urban scale, energy is part of the history of urban facilities and services (Tarr and Dupuy 1988; Caron 1990). This literature has been used to highlight the quantitative approach, considering infrastructures as the material link between the environment and the city (and vice versa) (Melosi 2000).

When these academic references were insufficient, primary sources were used, mainly from the technical and administrative literature of the periods considered, and to lesser extent from archives (Archives nationales, Archives de Paris). Both primary and secondary sources proved very useful for the quantitative analysis.

\section{Case study and data}

The case study and its boundaries

At the beginning of the eighteenth century, Paris was an administrative unit covering around $34 \mathrm{~km}^{2}$ with the entire local urban population (Figs. 2, 3). After the French Revolution, Paris was included as a municipality (consisting of 12 arrondissements) in the Seine département $\left(394.78 \mathrm{~km}^{2}\right)$, surrounded by the rural Seine-et-Marne and Seine-et-Oise départements. During the nineteenth century, like other European cities, Paris experienced tremendous urbanization and population growth. The Paris city limits were extended in 1860, including some $38 \mathrm{~km}^{2}$ and about 400,000 inhabitants, so its area reached $78 \mathrm{~km}^{2}$ and its population 1.7 million inhabitants. In 1921, 2.9 million inhabitants were living in Paris (its maximum population), a 5.3-fold increase compared with 1801. Paris gained military areas (the fortifications were demolished) in 1919 and two surrounding forests in 1946, so its area increased to $105 \mathrm{~km}^{2}$ and has not changed since then. Its population decreased, especially during the 1960-1980 period, and now seems to have stabilized to slightly more than 2 million inhabitants.

Paris is included in Ile-de-France, a region whose administrative boundary was drawn during the 1960s. Ilede-France is composed of eight départements including Paris itself, which also has the status of a département. Until the end of the nineteenth century, Paris hosted nearly the entire urban population. The suburbs have grown in population and area, mainly since 1870 , and their population has exceeded the population of Paris since the 1950s (Fig. 3). Generally, the Ile-de-France region is divided into three different areas according to their urban characteristics; city center (Paris municipality), the immediate suburbs (called the Petite Couronne, PC), and the rest of the region (called the Grande Couronne, GC). PC includes three administrative départements (Hauts-de-Seine, SeineSaint-Denis, and Val-de-Marne), which have developed since the late nineteenth century, at first with industrial activity and today with dense residential areas. GC is made up of four départements (Seine-et-Marne, Yvelines, Essonne, and Val-d'Oise), which have developed since the early twentieth century and are now characterized by urban sprawl, industrial activities, and intensive agriculture.

Data sources are abundant for Paris compared with other cities, but they most often concern Paris within its administrative limits. This is why the system under study in the following sections consists of Paris as an administrative entity (a municipality and a département) and not as a wider urban area-even if considering the urban area as a whole would have been valuable. Final energy consumption (TFEC) and direct energy consumption (DEC) were assessed on this basis. For primary conversion, the total energy requirement (TER), supply area and supply distance,

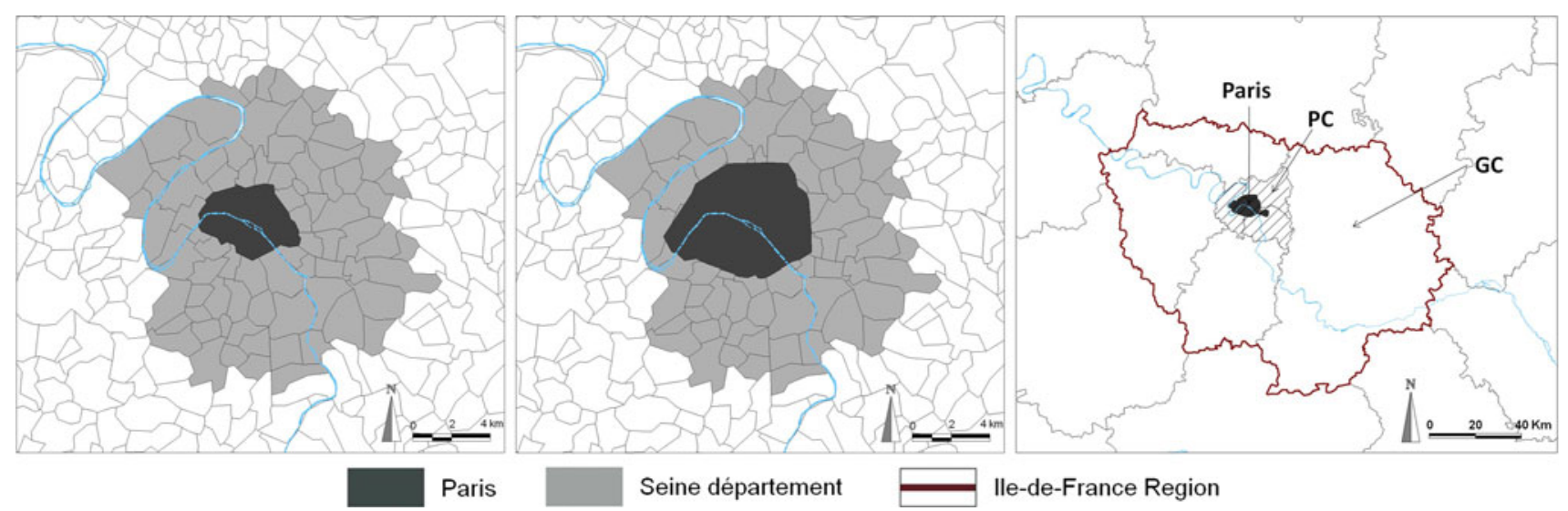

Fig. 2 Paris with its old Seine département (see text) in 1810 (left) and in 1870 (middle) and in Ile-de-France region in 2006 (right) 


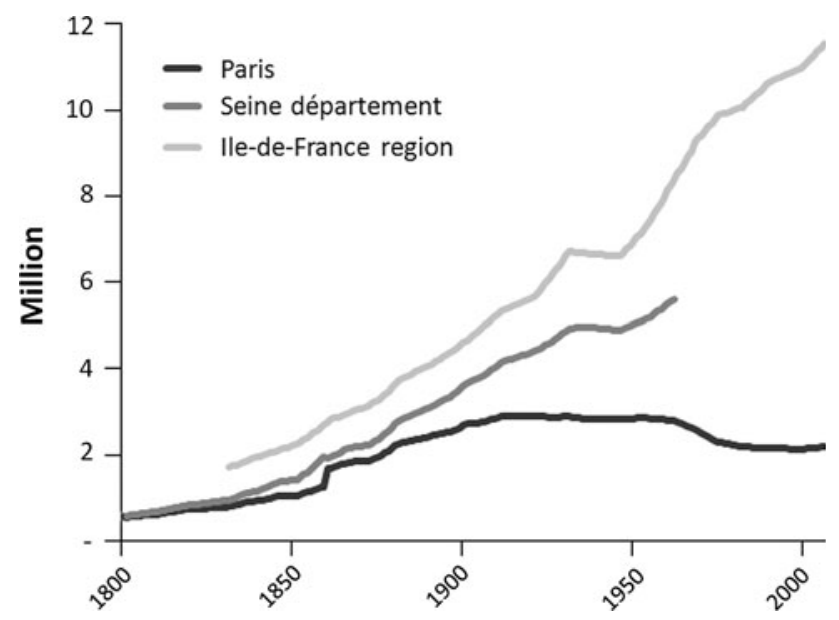

Fig. 3 Population of Paris, Seine, and Ile-de-France region from 1700 to 2006 in millions of inhabitants

however, it has been necessary to collect data outside of the study area. From 1816 to WWII, most energy transformation occurred in the Ile-de-France region (outside of Paris). After 1945, transformation units moved outside of the regional boundary and even the national boundary.

\section{Data sources}

Data for biomass energy consumption-mainly firewoodfor the period before 1800 was reported by Barles (2009b). For final energy consumption, mainly the data from the city toll was used for the 1800-1945 period and data from the official statistics after 1945 (INSEE). The conversion factor from mass to volume and the calorific value were based on contemporary literature (Bonnet 1874; Peclet 1844; De Saint-Julien and Bienaymé 1887; Chevalier 1832) for the nineteenth century. After 1945, coefficients were obtained by official energy statistics (DGEMP 2002, UN 1982). Manufactured gas and electricity consumption, which were not taxed by the city toll, were based on data from the Paris gas and electricity companies reported in the literature (Barjot et al. 1991; Williot 1999; Malegarie 1947). Not surprisingly, the data are fragmentary, with different physical values and equivalence factors. They were converted to joules considering the different equivalence factors at the time. The national production yield and mix ratio were obtained mainly from the national statistical data (INSEE 1980), and the PEGASE energy database (PEGASE-DGEMP 2009) and completed by data from the literature (Larroque 1997; Malegarie 1947; Williot 1999) for the nineteenth century. Production and distribution yield factors were obtained from the analysis of primary energy input and secondary energy output. Energy sector internal consumption was subtracted from gross energy production and considered to be transformation losses. Distribution losses were defined as the difference between net production and energy delivered to the final consumer. Greater detail on the production and distribution yield factors and the primary energy source mix in the final energy consumption figures was presented in a previous paper (Kim and Barles 2010).

The energy supply area for Paris was analyzed for selected years according to the quantitative results presented in section "Quantitative results": 1778-1810, 1870-1880, 1960-1965, and 2006, each characterizing a particular energy regime. The $1778-1810$ period is marked by the end of the biomass-dependent energy system and the peak in wood use. In 1875, the energy and supply situation was vastly different, because of the dominance of coal and the changes in the transportation systems. In accordance with the literature (Boissiere 1990), we considered that the source of the firewood did not change during the second half of nineteenth century. The 1960-1965 period is characterized by a tremendous increase in the per capita total energy requirement and also by the development of the supply system at the international scale. The most recent year with available data for freight is 2006 . For the 1778-1810 period, the wood supply area was obtained from Reze (2002) and the sources of coal from Chevalier (1832), completed by other literature (Peclet 1844; Comte de Chabrol 1829; Barjot et al. 1991). For the year 1875, import data from the Paris manufactured gas company (Williot 1999) and other sources (Minard 1858; Jacqmin 1868, 1878; Przybyla 2007) were used. The energy supply in 1960-1965 was obtained from the literature (Musset 1959, 1962, Beaujeu-Garnier and Bastié 1967), the IRSN database for uranium (MIMAUSA 2010), pipeline import data (TRAPIL 1963, 1972), and regional and national statistics (INSEE 1966a, b).

For the year 2006, the French freight transport database (SITRAM) was used to estimate the sources of energy consumed in Paris, except for uranium and waterpower. SITRAM data include the entire national freight and direct imports from foreign countries. Given that some products are not directly transported from where they are extracted to their place of consumption (Paris), SITRAM data were completed with Eurostat data (2008) to estimate the true source of imports from non-producer exporters to Paris (mostly neighboring European countries such as Belgium, Holland, and Spain). The energy exchange between other countries outside of Europe was not evaluated, and imports from non-EU countries were considered direct imports. Production data for the French region and other European countries was integrated into the database. The data for energy production in the French regions comes from the national energy database (PEGASE 2010) and primary energy production of foreign European countries comes from Eurostat (2008). For uranium and waterpower, AREVA reports (Areva 2004) and PEGASE database were 
used, respectively. We made the assumption that the origin of uranium, waterpower, and natural gas directly or indirectly consumed by Paris was the same as the origin of uranium, waterpower, and natural gas directly or indirectly consumed in France.

\section{Quantitative results}

\section{Energy consumption}

Figure 4 shows the per capita total final energy consumption (TFEC) by final energy source, and Fig. 5 shows the per capita TER by primary energy source (e.g., the proportion of coal used for electricity generation in the TER is found in the coal section). In per capita TER, four phases were observed: growth during the second half of the eighteenth century, stabilization from 1800 to 1920 , a huge increase from 1920 to 1980 (a fourfold increase with a $1.6 \%$ average annual growth rate), and a smaller increase from 1980 onwards (with a $0.6 \%$ average annual growth rate). The first three phases are quite similar in terms of per capita TFEC, but the impact of the 1970s crisis is much more apparent, and the last phase shows a trend toward stabilization in final energy consumption.

Around 1730, each Parisian consumed approximately 15 GJ per year (roughly $1.5 \mathrm{~m}^{3}$ of cut wood) of final energy (per capita TFEC) and the per capita TER was about 19 GJ per year. Per capita TER increased significantly during the second half of the eighteenth century and reached almost $30 \mathrm{GJ}$ per capita per year at the beginning of the nineteenth century. During this century, the population grew rapidly, much more than per capita TER: while the population increased fivefold, TER remained between 25 and 30 GJ per capita per year, so Paris's TER increased from 18 to 72 PJ per year. From 1945 to the middle of the 1960s, Paris's population stabilized (Fig. 3), and per capita TER grew rapidly: compared to 1900 , it doubled at the beginning of the 1950s and tripled in the 1960s. After 1970, TER still increased but the growth rate was moderate compared with the period before 1945-1965, so it remained around 100-120 GJ per capita per year and TFEC around 60-65 GJ per capita per year. In 2006, Paris's TER and TFEC reached, respectively, 276 and $161 \mathrm{PJ}$ per year.

Paris was totally dependent on biomass energy until 1800 , and the energy transition to fossil energy began at the beginning of the nineteenth century. Coal reached about $50 \%$ of TER during the 1850s and peaked during the 1930s1950 s, accounting for almost $80 \%$ of TER in the 1930s. Since the decline in coal consumption, petroleum began to grow and reached $70 \%$ of TER in the 1970s. After 1970, a diversification of energy sources can be observed. The comparison between fossil energy (coal, natural gas, and petroleum) and biomass energy consumption shows that biomass consumption remained significant until the 1910s, accounting for $10 \%$ of TER. Its consumption ended in the 1940s. Fossil energy reached almost $80 \%$ in 1890 . Then it amounted more than $90 \%$ of TER from the 1910s to the 1970s.

Supply distance and supply area

Table 1 presents the average and the maximum distance $\left(D_{\text {avg }}\right.$ and $D_{\text {max }}$ ) between the city and its primary energy sources, comparing four different periods. Figure 6 shows the geographic origin of energy consumed in Paris during these four periods. The average value is an important indicator that explains the limit of supply area related to the city's technical and economic conditions. The maximum
Fig. 4 Total final energy consumption (TFEC), Paris, 1730-2000 GJ/cap/year. Firewood includes firewood and charcoal in final terms. Gas includes manufactured and natural gas in final terms

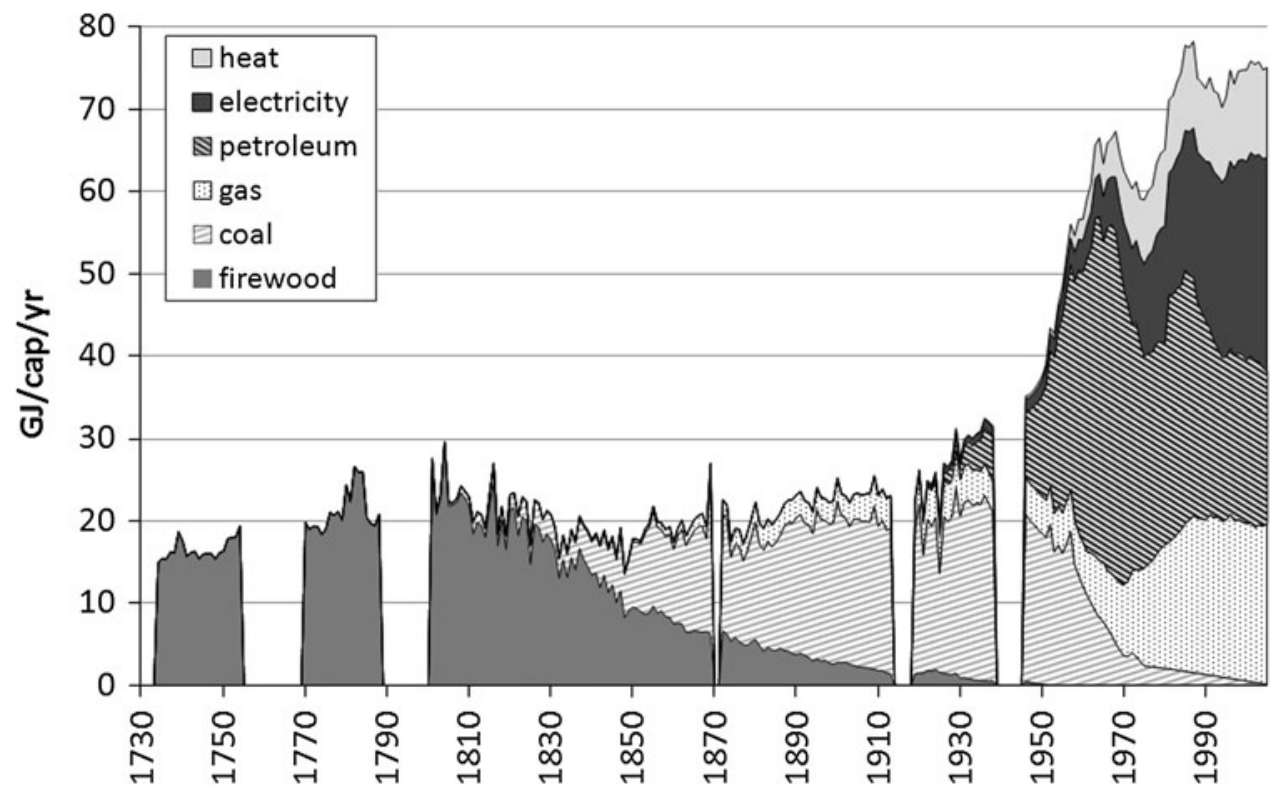


Fig. 5 Total energy requirement (TER), Paris, 1730-2000 GJ/cap/year. Firewood includes firewood and charcoal in primary terms. Primary electricity includes nuclear and other renewable sources in primary terms

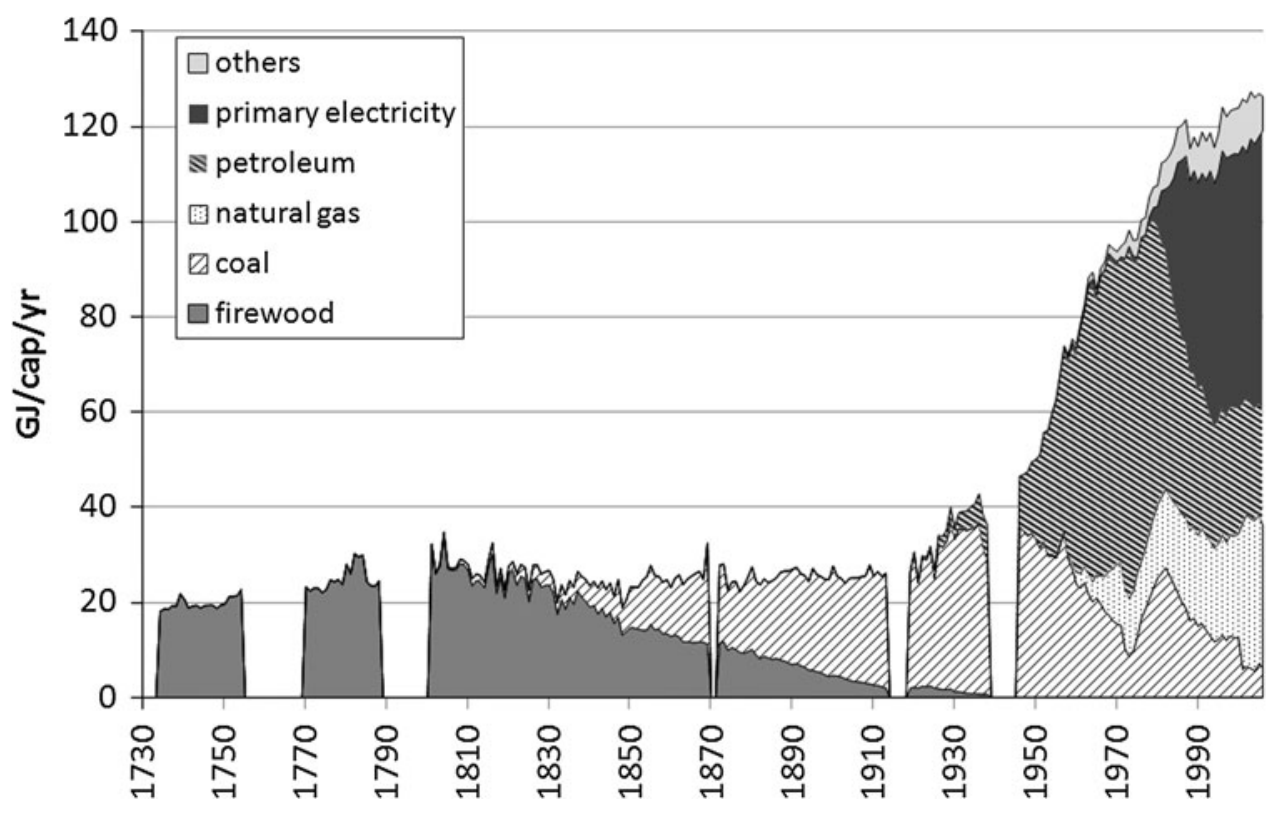

value is therefore significant, showing the maximum accessibility, which may explain (1) existing important resources but with economic constraints or (2) the existing supply network planned to achieve a competitive economy in the future (see the next section).

At the beginning of the nineteenth century, the $D_{\text {avg }}$ remained below $200 \mathrm{~km}$. It increased by more than $40 \%$ from 1800 s to 1870 s. The gain in $\mathrm{D}_{\mathrm{avg}}$ for all energy sources was due to the main energy resource changing from wood $\left(D_{\mathrm{avg}}=190 \mathrm{~km}\right)$ to coal $\left(\mathrm{D}_{\mathrm{avg}}=330 \mathrm{~km}\right.$ in the $\left.1870 \mathrm{~s}\right)$ in TER. The $\mathrm{D}_{\mathrm{avg}}$ for coal in the 1870 s was almost unchanged. The $\mathrm{D}_{\max }$ therefore increased from 370 to $790 \mathrm{~km}$. From the 1870 s to 1965 , the $\mathrm{D}_{\mathrm{avg}}$ increased from 270 to $2700 \mathrm{~km}$. Except for petroleum, the $\mathrm{D}_{\text {avg }}$ for each energy source did not exceed $600 \mathrm{~km}$. The distance from the coal supply area was the same in 1965 as in 1875 . The most decisive factor was the increase in the quantity of imported petroleum: petroleum was imported from a distance of $3850 \mathrm{~km}$ and accounted for almost $70 \%$ of TER in Paris. Consumption of natural gas coming from faraway sources also increased (even if it was not as large in terms of consumption, it impacted the $\mathrm{D}_{\mathrm{avg}}$ ). Between 1965 and 2006, the $\mathrm{D}_{\mathrm{avg}}$ increased $40 \%$, from $2700 \mathrm{~km}$ to $3850 \mathrm{~km}$, whereas the $\mathrm{D}_{\max }$ rose more than $100 \%$, from $7350 \mathrm{~km}$ to $15,330 \mathrm{~km}$. Compared with the previous periods, the coal supply area extended from approximately $300 \mathrm{~km}$ to $6100 \mathrm{~km}$ in 2006 , nearly a 20 -fold increase in the $\mathrm{D}_{\text {avg }}$ for coal. The $\mathrm{D}_{\text {avg }}$ for each energy source significantly increased from 1965 to 2006, more than $1900 \%$ for coal, more than $300 \%$ for natural gas, and $1100 \%$ for the nuclear resource, although petroleum maintained almost the same value (Table 1).

An increase in the diversity of both energy sources and their geographic origin was observed particularly during the second half of the twentieth century (in 1965 and 2006). The coal and petroleum supply, which were dependent on both national and international sources in 1965, are now nearly entirely dependent on foreign sources. The natural gas and uranium supply, only national in 1965, completely depended on foreign countries in 2006.

In $1800,70 \%$ of the coal consumed in Paris was transported by waterways and waterways transported more than $80 \%$ of TER. In the 1870 s, coal was transported equally by waterway and railway. In 1965, much more diverse transportation means were in use than previously, due to new transportation systems such as the electricity network transporting hydropower and pipeline systems adopted for petroleum and natural gas. From 1875 to 1965, sea transportation increased, mainly because of the rise in petroleum imports. From 1965 to 2006, railway and the inland waterway transport almost disappeared (less than $1 \%$ for the former, approximately $1 \%$ for the latter) and the proportion of road transportation and the pipeline system increased (from 5 to $9 \%$ for the first and from 6 to $16 \%$ for the second), owing to an increase in petroleum road transportation and in natural gas consumption.

Secondary energy and losses

During the last two centuries, Parisians' secondary energy consumption gradually increased, as did the transformation sector that was at first concentrated close to the city walls, then was set up within the region. The regional contribution to Paris's energy consumption decreased from $100 \%$ in 1875 to $82 \%$ in 1965 and to $36 \%$ in 2006 .

During the nineteenth century, the gas sector increased its production and distribution yield considerably from 60 
Table 1 Primary energy source share and supply distance in 1800 , 1875,1965 , and 2006

\begin{tabular}{|c|c|c|c|c|}
\hline & $1800 \mathrm{~s}$ & $1870 \mathrm{~s}$ & $1965 \mathrm{~s}$ & $2006 s$ \\
\hline \multicolumn{5}{|c|}{ Part of each primary sources in TER $(\%)$} \\
\hline Wood & 97 & 42 & 0 & 0 \\
\hline Coal & 3 & 58 & 25 & 5 \\
\hline Petroleum & 0 & 0 & 67 & 19 \\
\hline Natural gas & 0 & 0 & 6 & 24 \\
\hline Nuclear & 0 & 0 & 0 & 44 \\
\hline Hydraulic & 0 & 0 & 1 & 2 \\
\hline Others & 0 & 0 & 2 & 6 \\
\hline Total & 100 & 100 & 100 & 100 \\
\hline \multicolumn{5}{|l|}{ Distance $(\mathrm{km})$} \\
\hline Wood & 190 & 190 & - & - \\
\hline Coal & 340 & 330 & 300 & 6,110 \\
\hline Petroleum & & & 3,850 & 3,970 \\
\hline Natural gas & & & 590 & 2,540 \\
\hline Nuclear & & & 400 & 4,910 \\
\hline Hydraulic & & & 460 & 460 \\
\hline Others & & & 50 & 50 \\
\hline Davg & 190 & 270 & 2,700 & 3,850 \\
\hline Dmax & 370 & 790 & 7,350 & 15,330 \\
\hline
\end{tabular}

to $80 \%$ for production and from 84 to $94 \%$ for distribution. The electricity production yield factor also increased from 10 to $50 \%$ during the twentieth century (for greater detail on secondary energy, see Kim and Barles 2010). In spatial terms, the improvements in production and distribution yield increased the output quantity per unit of installation. Together with the enhancement in distribution yield, it allowed the network to be extended and increased the area that can be supplied by one unit, the distance among the units and to the consumption area. For Paris, those factors interact together and impact the city's direct and indirect consumption.

For the gas sector during the nineteenth century, both transformation efficiency and consumption increased with the same average annual growth rates of $0.3 \%$. For electricity (the main secondary energy in the twentieth century), these rates reached 2 and 6\%, respectively. In Paris, slightly decreasing per capita TER from the middle of the nineteenth century to the beginning of the twentieth century seems to have resulted from the yield factor increase: both in conversion from primary to final energy in the gas sector and in conversion from final to useful energy in individual thermal and mechanical devices such as the coal furnace or the steam engine. It was then possible to produce the same amount of useful and final energy with a smaller amount of primary energy.

In time, the total losses associated with Paris's final consumption (TER - TFEC) increased with growing energy consumption and the increasing proportion of secondary energy in TER. It was more significant during the twentieth century. The indirect flow associated with secondary energy imports, both in quantity (TER - DEC) and in ratio (TER/DEC), has tended to increase since the beginning of the nineteenth century (see Fig. 7), in relation to increasing secondary energy consumption and the production units' remoteness from the city. Furthermore, the contribution of indirect flows (that is to say losses that occur outside Paris) to total losses increased dramatically. In 1875 , about $50 \%$ of energy losses related to Paris consumption occurred outside Paris, reaching $80 \%$ in 1965 and 97\% in 2006 (see Fig. 7).

\section{Discussion}

Firewood consumption and energy shortage during the eighteenth century

During the eighteenth century, firewood was the main fuel used in Paris. With the high volume and mass of wood per calorie obtained, road transportation was prohibitive and limited firewood and charcoal exported to Paris. Floating (and to lesser extent boat transport) was used as the main means of transporting of this commodity. Around 1800, two-thirds of Paris firewood came from Morvan, in the southeastern part of the Seine basin, more than $200 \mathrm{~km}$ from the city, mostly accessible by river (Fig. 8).

Population growth added to the demand for luxury and thermal comfort among the aristocracy during the second half of the eighteenth century, so wood demand increased in Paris until the French Revolution, increasing TFEC and TER. The supply was not sufficient as wood was not only used for households and bakeries, but also as a construction material and for industrial production. A wood shortage started in the middle of the eighteenth century and continued until the beginning of the nineteenth century in Paris (Guillerme 1992; Touzery 1995; Barles 2009b).

This was a matter of concern for the Paris municipal government because the energy supply was under its responsibility. Rivers had to be adapted to floating and navigation (Benoit et al. 2003). The entire Seine basin was monitored by Paris in order to supply the city with wood, to secure its arrival and to diminish losses during its long journey: between 1 and 3 years from the forest to the consumer. This was the main concern of the local energy policy but did not prevent the wood crisis at the end of the eighteenth century: the apparent stability of energy supply during the eighteenth century hides the profound change that was occurring in society, namely, 


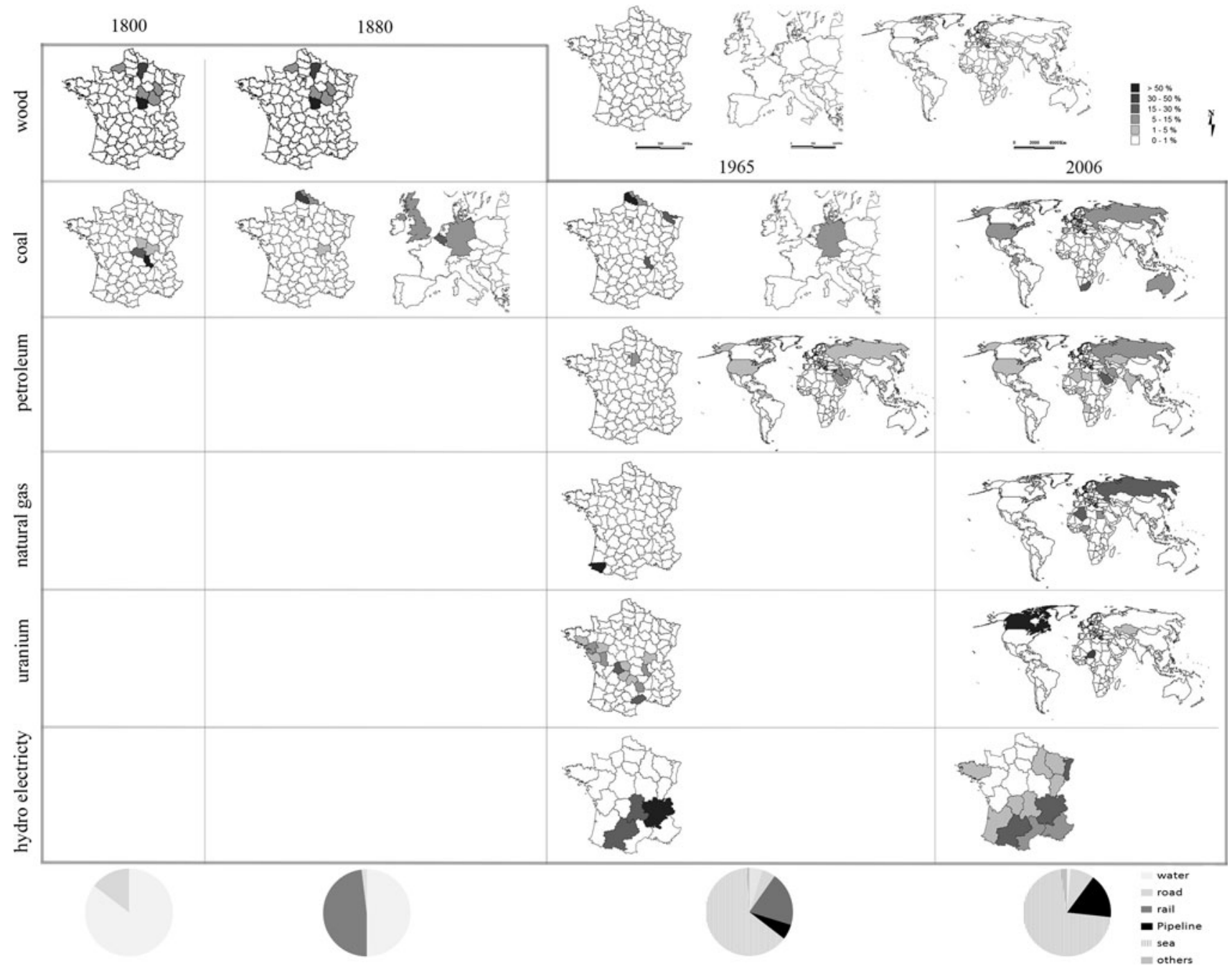

Fig. 6 Energy supply area and proportion of different transportation modes (source: see text)
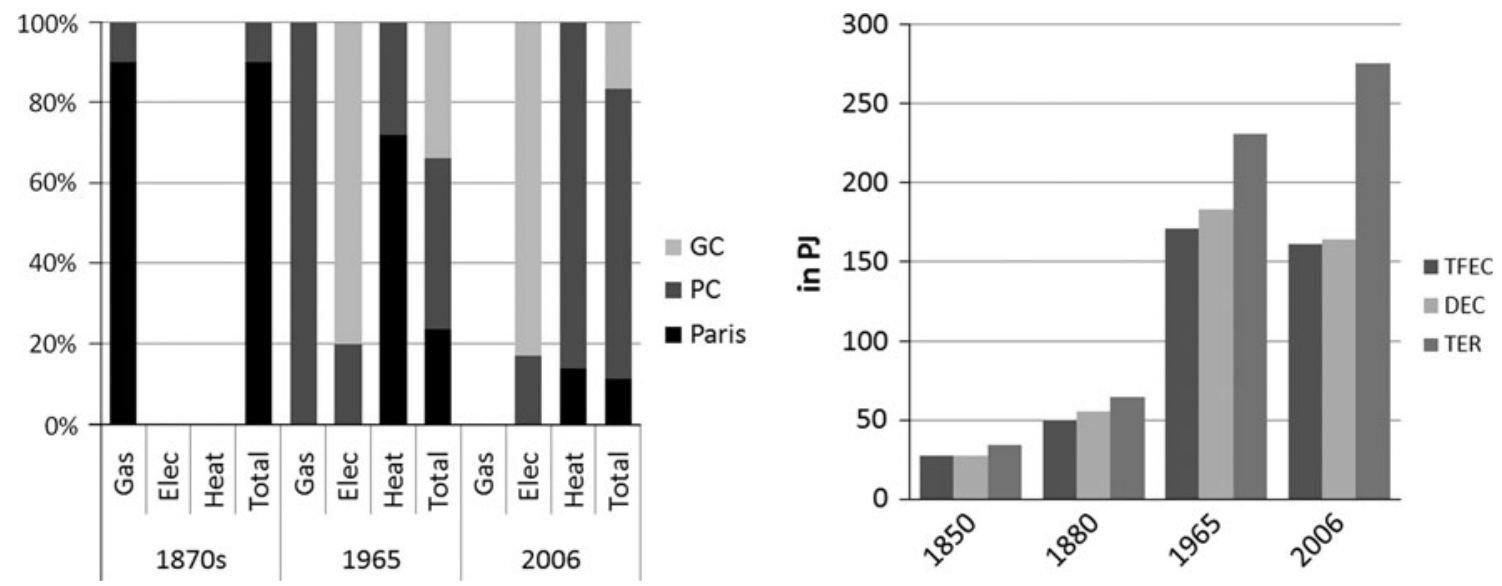

Fig. 7 Location of Paris's final energy production in 1880, 1965, and 2006. Percentage of final energy production at different spatial scales in 1870s, 1965, 2006 (left) and TFEC, DEI, and TER (right) in 1850, 1880, 1965, and 2006 (source: see text)

the advent of consumption. The noun "consumer" appears more and more frequently in manuscripts and printed texts related to energy to designate urbanites, and the noun consommation (consumption) acquires its modern meaning in the French language at the same time (Barles, in preparation). 

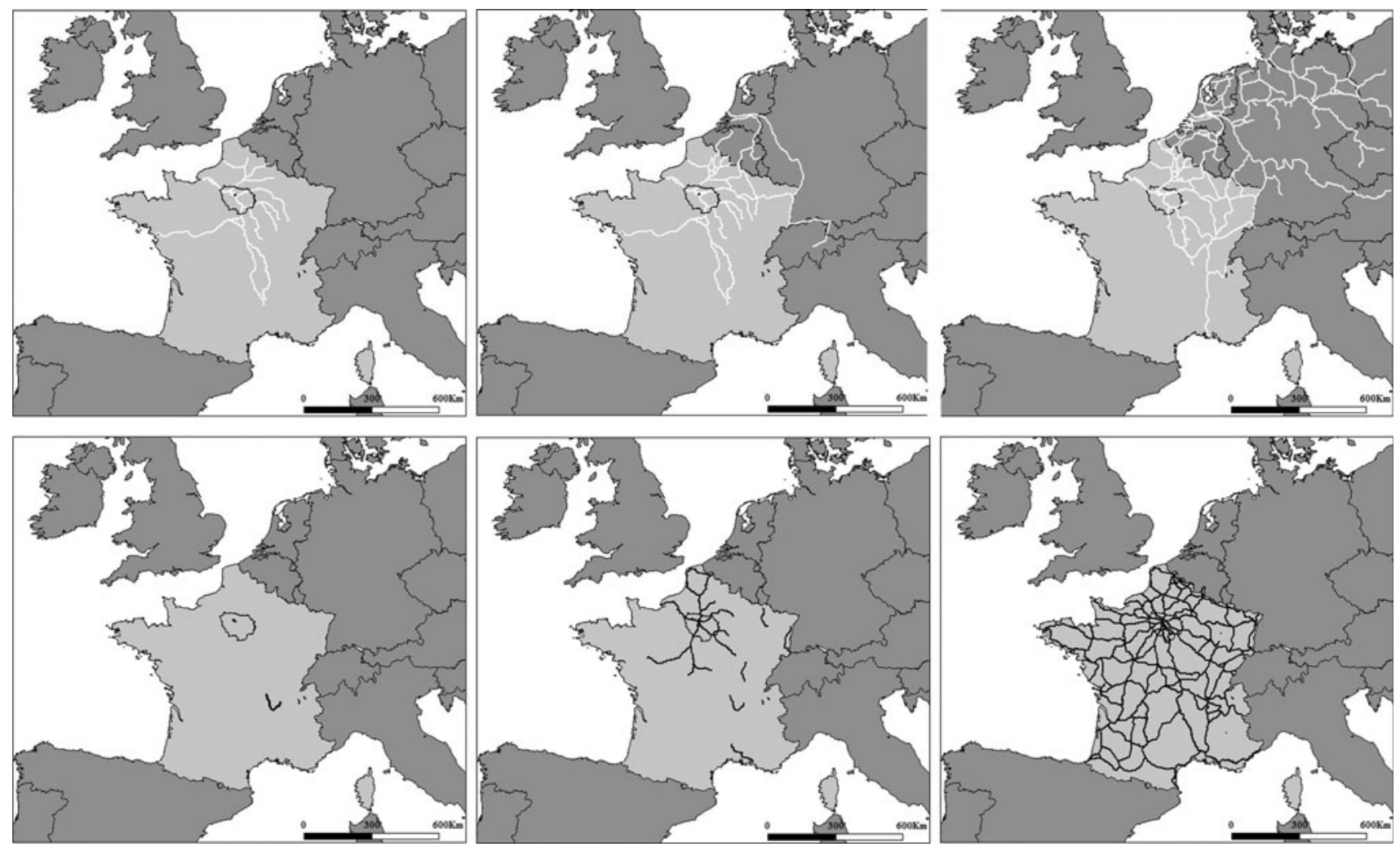

Fig. 8 Waterways in 1800, 1870, 2005 (top, white lines) (Pinon 2001; Renouard 1960; VNF 2007) and railway network development in 1837, 1850, 1870 (bottom, dark lines) (Caron 1997; Sougy and Verley 2008)

Transportation network extension and changing energy supply area during the nineteenth century

The main change during the nineteenth century did not apparently influence the per capita consumption (see Figs. 4, 5). Surprisingly, it remained quite stable throughout the nineteenth century, despite rising living standards and the progressive shift from luxury to comfort (Goubert 1988; Guillerme 1992). One hypothesis is that the conversion from TFEC to useful energy became more efficient as a result of energy savings related to many technical improvements in energy devices, a process that the indicators used herein cannot highlight and that should be analyzed in depth.

However, the quantitative results clearly show the energy transition from biomass to fossil fuel and from surface to underground energy sources. Before the nineteenth century, coal was an unpopular fuel and demand was low. From 1810 on, coal consumption increased regularly, showing a 5\% annual growth rate. Per capita consumption was moderate, but the population of Paris increased from 0.55 million at the beginning of the century to about 2 million in the middle of the 1870s. From 1800 on, household coal consumption was encouraged by public authorities as a way to resolve the wood crisis; beginning in the 1810s, gas production began in Paris, at first for public lighting, later for household heating, lighting and cooking; simultaneously, the use of the steam engine developed in the capital (Daumas 1976; Williot 1999).

Providing Paris with coal required a complete change in the energy supply route and resulted in a tremendous change in supply areas, even if supply distances did not experience significant variations. The transportation system was a matter of great concern for both public authorities and private investors. A general canalization policy developed beginning at the end of the eighteenth century in order to interconnect water basins and to provide access to natural resources (see Guillerme 1991). Railway construction started during the 1830 s and covered nearly all of France by the 1870 s. It began to supplant waterways for energy transportation during the second half of the nineteenth century (Fig. 8).

According to Chevalier (1832), until 1810, almost all of the coal consumed in Paris came from France's southern coal basins, mostly from Saint-Etienne in the Loire département, located $370 \mathrm{~km}$ from Paris. Transportation costs were very high and accounted for nearly $80 \%$ of the price of the coal coming from Saint-Etienne (Chevalier 1832). The real travel distance was more than $500 \mathrm{~km}$ from Paris. Transportation conditions at the beginning of the 
nineteenth century were very irregular on rivers and canals depending on the climate conditions, and especially droughts or freezing, taking from several weeks to several months to arrive in Paris (Chevalier 1832). The production in southern mining basins was insufficient to supply Paris, considering its increasing demand but also due to the demand of other southern cities (Observation 1816). Therefore, finding more productive basins and providing a regular supply were two essential issues at the beginning of the nineteenth century in Paris (Chevalier 1832; Dutens 1829).

After 1810, the coal supply area expanded toward northern coal basins, particularly to Belgium, which had abundant production within $180-230 \mathrm{~km}$ of Paris. Many canal construction works to the north had already started during the second half of the eighteenth century and ended during the first half of the nineteenth century. The SaintQuentin canal construction was completed in 1810 and the Mons-Condé canal in 1818 (Chevalier 1832; Pinon 2001) (Fig. 8). They gave Paris access to northern and Belgium coal supplies interconnecting the Seine basin and the Somme basin. After 1810, these regions became the largest energy providers to Paris. Later, in the 1850 s, the construction of a junction canal from the Marne to the Rhine River and of the railway allowed access to German coal. Actually, railway development dramatically changed the energy supply conditions from 1850 s onwards. It extended the supply area (Flachat 1858), but the real extension was allowed after 1878, especially with the end of the tollage system on ports (D'Avenel 1919). During the second half of the nineteenth century, while national coal basins increased their production continuously, consumption also increased. Therefore, foreign imports grew: compared to 1830 , in 1880, national production increased tenfold, but foreign imports increased 14-fold. According to national data, the northern coal basin in France produced approximately $40 \%$ in 1865 and $60 \%$ in 1880 of the total national coal production. The coal supply area extended physically, reaching England and Germany. Nevertheless, northern basins (in the North and in Belgium) still remained the main source of the coal consumed in Paris.

Increasing energy consumption and expansion of the energy supply area up to the 1960s

The increase in per capita consumption (TFEC and TER) began after WWI in Paris in spite of the city's de-industrialization: heating (together with water provision and later sanitation) became a priority, the rise of motorization in public, private, and freight transport together with increasing mobility triggered an increasing energy demand, and again, an energy transition that influenced all aspects of supply: energy sources, energy use, energy conversion, supply areas, supply distance, and supply routes.
The energy supply chain for coal had been established at the western European scale since the 1870s, and the geographic sources remained the same up to the 1970s. Nevertheless, the global energy landscape totally changed during the first half of the twentieth century, due to increasing petroleum and natural gas consumption. France started to build its petroleum supply chain as early as the 1910 s by creating the national petroleum committee in 1917 (Peyret and Courau 1935). Later, during the 1920s and the 1930s, oil refineries were constructed in BasseSeine to supply Paris (Musset 1959, 1962). Consequently, the geographic change was notably related to the transportation network for primary energy supply to the city (Fig. 7). Moreover, this change influenced the energy transformation sectors in the region during the 1960s (see section "Changes in primary sources and spatial consequences in energy transformation", Fig. 7).

Before 1924, oil was mostly imported from the United States through the port of Le Havre. Inland transportation mostly occurred on waterways (INSEE 1966b; TRAPIL 1963). The pipeline system was not considered for the Parisian region before 1945 because construction was expensive and only profitable for mass consumption (Peyret and Courau 1935). After WWII, increasing petroleum consumption spurred the construction of the first pipeline, which was put into service in 1953. At the end of the 1950s, the city's increasing demand made the construction of a new pipeline necessary to double the existing transport capacity.

Another important change concerned gas. During the 1950s, the Paris gas network was connected to AlsaceLorraine coke and gas factories, where the primary energy was entirely coal. In 1959, Paris became one of the first cities in France supplied by natural gas extracted in southwestern France (gaz de Lacq) (Beltran 1992). Beginning in the mid-1960s, natural gas started to come from North Africa and then Holland.

Globalization of the energy supply area at the beginning of 21 st century

In 2006, Paris's primary energy supply area was not very different from the national energy supply area. This tendency toward homogenization was a long-term process that began during the nineteenth century. The major energy supply chains (fossil fuel and nuclear energy) today operate at the international scale. The slight dependency on northern Europe shows both the historical heritage (particularly related to port activity) and the effect of public policy at the European scale. At the end of the 1970s, national and regional energy planning, firstly, promoted diversification of energy sources in order to reduce the dependency on oil and on specific supply areas (Conseil 
Régional de l'Ile-de-France 1984). Secondly, they encouraged regional primary energy production as well as energy savings in buildings. Paris increased its energy production by waste incineration, which impacts the energy supply distance as well as the location of transformation units (see section "Changes in primary sources and spatial consequences in energy transformation", Fig. 7).

In 2006, Le Havre was the major entering point for the petroleum products supplied to the Paris region, while Marseilles, another major oil importing port, provided petroleum to the southern part of France. Nevertheless, the sources of petroleum products are highly diverse compared to 1965 , including many transit transports through neighboring European countries such as Belgium and Holland. From the 1970s on, Paris's petroleum consumption decreased, most notably its domestic and industrial use. The first was replaced by electricity and then by natural gas, and the second decreased as a consequence of industrial relocation.

Natural gas accounts for 25\% of TER in Paris and originates $2500 \mathrm{~km}$ from the city. More than $50 \%$ of natural gas comes from the North Sea in Europe, with other important supply areas in Algeria and Russia. The supply from foreign countries to the French border is transported both by pipeline and sea transportation: $70 \%$ for the first and $30 \%$ for the second. Inland transport comes entirely by pipeline, which is not accounted for in the freight transport database (SITRAM 2006). The gas supply is similar for Paris and the rest of France-nevertheless, the provision from the North Sea and Russia can be higher for Paris because it is located closer to the junction between the Russian and northern European gas pipeline (DGEMP 2007)

In the 1960s, coal consumption dropped rapidly. At the national scale, coal peaked at the end of the 1960s and the coal industry declined thereafter. During the second half of the 1960s, the coal supply area began to move toward the United States, Poland, South Africa, and Australia, which are the coal supply areas for 2006 (Fig. 7). The coal-related industry declined not only in France but also in western Europe, on which Paris had been dependent for its coal supply since the late nineteenth century.

Primary energy production at the regional scale became important after 1980. The most important local energy sources were geothermal and waste incineration, with a very small amount from other renewable energies and about 450 ktep (about 18 PJ) of oil production in GC (see "The case study and its boundaries"). The energy produced by waste incineration for heating began to be consumed in the 1940s. Since 1970, heat consumption and the proportion of wastes in total primary energy in the sector have grown. During the 2000-2005 period, it accounted for almost 50\% of heat produced by the sector and 5\% of TER of Paris.
The main characteristic of the present-day energy supply is its globalization (Fig. 7)—not a surprise given the general economic context-together with an attempt to develop local energy sources. This creates a kind of polarization of the energy supply between local and global markets, the latter being much greater in terms of consumption and the first in terms of politics and local political involvement. One of the consequences of globalization is that, despite the stabilization observed in per capita TFEC (and TFEC as a whole, as the Paris population has changed little in the past 20 years), per capita TER continues to increase, even if its growth rate is lower than in the previous period.

Changes in primary sources and spatial consequences in energy transformation

The changes observed in the energy regime not only concern the supply areas but also the transformation sector and its location.

During the nineteenth century, the major drivers concerning energy and the location of energy transformation were local: an increase in energy demand that required the construction of larger gasworks, a tax system (city toll) that encouraged the installation of plants outside the Paris administrative limits, pollution problems, and regulations that made it difficult (if they were not outright prohibited) to set up plants near housing districts. At the beginning of the twentieth century, electricity consumption became significant and, following the same principles, it was entirely located outside of Paris in PC. Limiting technological variables (such as losses in transformation and transportation; see section "Secondary energy and losses") together with the locally driven energy policy (even if the national level had gained importance throughout the nineteenth century) resulted in the concentration of the transformation sector around Paris.

The technological variables changed from the end the nineteenth century on: increasing yields, networking and changes in primary energy sources impacted the transformation sector and its location, which became much more dependent on the national context and policy-especially since 1945 with the nationalization of the energy sectorand on the international energy market, in the context of increasing demand.

During the interwar period, the electricity network began to extend to mountainous regions such as the Alps and the Massif Central where hydroelectricity was produced. However, in quantitative terms, imported electricity was marginal compared with the regional transformation based on coal. After 1945, it extended again toward the northern region to import the electricity produced by coal. In the 1960s, approximately $80 \%$ of electricity was 
produced in the region, $20 \%$ of which was produced in PC and $60 \%$ at its periphery (GC) (Table 2). Simultaneously, manufactured gas production moved to eastern France and then disappeared in the 1960s when it was replaced by natural gas. For the heat distribution sector, most of the construction of units was completed in the late 1960s.

The oil crisis during the 1970s impacted the electricity and heat sector. The primary energy transition in the electricity sector, from fossil energy to nuclear electricity, has marginalized the regional production since 1980. Until 1980, energy was transformed into heat in Paris from petroleum products (about 70\%) and outside of Paris from waste products $(30 \%)$. The oil crisis influenced both the change in primary energy sources and the location of transformation units. In terms of quantity, the major production moved out of Paris, increasing the proportion of heat produced by coal and waste incineration.

In 2006, the gas transformation sector had long disappeared and electricity came mostly from outside the region. About $85 \%$ of the heat was produced in PC and only $15 \%$ in Paris. The region produced only $10 \%$ of the electricity consumed within the region. The renovation of the regional factories with combustion turbine power plants began after 2000 to adapt to a new context: regional production was now considered an extra source of electricity intended for use during seasonal peaks. In terms of total final production, more than $60 \%$ of final energy consumed in the region was produced outside of its boundaries. This, added to the growing importance of indirect energy flows (section "Secondary energy and losses"), shows the relevance of analyzing the remote dimensions of urban metabolism.

Table 2 Percentage of secondary production (total weighted by TFEC ) at different spatial scales in the Ile-de-France region for 1875 , 1965 , and 2006

\begin{tabular}{clllll}
\hline & Paris & PC & GC & Total region & Import $^{\text {a }}$ \\
\hline $1870 \mathrm{~s}$ & & & & & \\
Gas & 90 & 10 & - & 100 & - \\
Elec & - & - & - & - & - \\
Heat & - & - & - & - & - \\
Total & 90 & 10 & - & 100 & - \\
1965 & & & & & \\
Gas & - & 70 & - & 70 & 30 \\
Elec & - & 16 & 62 & 78 & 22 \\
Heat & 72 & 28 & - & 100 & - \\
Total & 19 & 35 & 28 & 82 & 18 \\
2006 & & & & & - \\
Gas & - & - & - & - & 90 \\
Elec & - & 2 & 8 & 10 & - \\
Heat & 14 & 86 & - & 100 & 64 \\
Total & 4 & 26 & 6 & 36 & \\
\hline
\end{tabular}

${ }^{a}$ Net imports from other regions

\section{Conclusion}

As the main level of decision making and governance of material and energy consumption, the national scale may be considered the most appropriate for the study of socioecological transitions and social metabolism. However, a growing trend toward local governance (e.g., the Plan Climat Energie Territorial in France) for more sustainable resource use makes it important to better characterize energy and material flows at the local scale. A city's metabolism can be differentiated from the nation's metabolism on at least two points: (1) substantial indirect flows that do not enter the city, and (2) very specific energy and material flows according to urban activities and land use that differentiate urban metabolism from the averaged national metabolism and even allow a differentiation within the urban area according to the main activities that take place in particular zones (for instance, residential and/ or tertiary function for the city center, the residential and/or industrial function for the suburban area).

Increasing energy demand both in TER and TFEC terms can be explained as a growing share of the metabolized (or appropriated in other terms) energy (in nature) by urban society. The role of the urban and extra-urban infrastructure is significant in this process of spatial and natural resource appropriation and was already well-known during the nineteenth century by economists and engineers (e.g., Jacqmin 1868). The structure in energy demand (both in TER and in TFEC) has changed remarkably since the end of the eighteenth century: from 1800 to 1920 , population growth was the main cause of the increasing urban energy demand, whereas between 1920 and 1980, per capita TER increased significantly; ironically, the transition occurred at a time when the city had reached its demographic maximum. The energy appropriated by the urban society between the late nineteenth to the middle of the second half of the twentieth century is remarkable both in quantity and quality: in TER and in distance from energy resources as well as in diversity in energy resources and their sources. It is also notable that the indicator of maximum supply distance $\left(D_{\text {max }}\right)$ tended to increase before the rise in average value $\left(\mathrm{D}_{\text {avg }}\right)$.

The structure of the area mobilized for the energy supply to Paris has changed since the eighteenth century. Until the end of the eighteenth century, the energy supply was a matter of biomass production and therefore land allocation. The growing energy demand directly meant an increasing demand for forest land. Since the beginning of the nineteenth century, when the proportion of fossil energy increased in TER, energy was less directly related to land allocation, i.e., to the direct surface dedicated to energy extraction. Otherwise, the networks necessary to connect resources to consumers extended significantly. The city's 
increasing energy demand in quantity terms is a major factor in this extension. However, it cannot be explained only in quantitative terms. The urban society also needed to provide regular and safe provision of energy against natural and economic hazards.

Since the end of the nineteenth century, Parisians have consumed more processed energy (e.g., charcoal, manufactured gas, electricity) over time, which means an increase in energy quality for the final consumer, but an increase in dependency on energy transformation sectors. Between 1826 and the end of the 1970s, secondary energy was produced mostly in the region. After the 1970s, these energy transformation sectors tended to move steadily further from the region. The remoteness of these sectors is allowed by increasing technical performance in transformation and distribution. The growing size of transformation units also made them difficult to locate near the consumer in urban areas, which were generally residential and dense. Spatial limitations played an important role because of the need for large areas for fuel storage and transportation (Chaline and Dubois-Maury 1983). These problems continued as the Paris area extended.

The factors that governed the city's metabolism and increased spatial impacts are numerous. As shown in Paris's energy supply history, the underlying processes of change over time are both natural and social. They depend on natural resource scarcity, opportunities for new technology, and social demand. As argued by environmental historians such as MacNeill (2001), energy, technical systems and the economy are intimately related in history. Paris as a capital plays the role of both the incubator and the first beneficiary of new technologies, as illustrated by coal-derived gas (Willot 1999), the steam engine (Daumas 1976), and pipelines (TRAPIL 1963). The increases in the city's energy demand and the increases that can respond to demand are simultaneous processes, both natural and triggered by humans, often difficult to separate into their natural and human components.

Acknowledgments The research presented in this article was funded by French National Research Agency (ANR-08-VILL-0008-02).

Open Access This article is distributed under the terms of the Creative Commons Attribution Noncommercial License which permits any noncommercial use, distribution, and reproduction in any medium, provided the original author(s) and source are credited.

\section{References}

AREVA (2004) Rapport annuel 2004, 372 p

Barjot D, Vuillermot C, Williot J-P (1991) L'énergie aux XIXe et XXe siècles. Presses de l'École normale supérieure, Paris

Barles S (2007) Feeding the city: food consumption and flow of nitrogen, Paris, 1801-1914. Sci Total Environ 375:48-58
Barles S (2009a) Urban metabolism of Paris and its region. J Ind Ecol 13(6):898-913

Barles S (2009b) Wood crisis and urban supply: Paris, 18th-19th centuries. Paper prepared for the international colloquim Cities and energy transitions: past, present, future organised by LATTS (CNRS). Autun, 1-4 juin

Barles S (2010) Society, energy and materials: what are the contributions of industrial ecology, territorial ecology and urban metabolism to sustainable urban development issues? J Environ Plan Manage 53(4):439-455

Beaujeu-Garnier J, Bastié J (1967) Atlas de Paris et de la région parisienne. Edition Berger-Levrault, Paris

Beltran A (1992) Gaz de France et le secteur gazier depuis 1940. Flux 8:29-38

Beltran A (2002) La ville-lumiere et la fée électricité: service public et entreprises privées: l'énergie électrique dans région parisienne. Rivedroite, Paris

Benoit P, Berthier K, Boët P, Reze C (2003) Les aménagements hydrauliques liés au flottage du bois, leur impact sur le milieu fluvial XVIe-XVIIIe siècles. In: Piren Seine, rapport d'activité 2002, on the web, 20 May 2009. http://www.sisyphe.upmc.fr/ piren/book/713

Besnard H (1942) L'industrie du gaz à Paris depuis ses origines. Ed. Domat-Montchrétien, Paris

Billen G, Barles S, Garnier J, Rouillard J, Benoit P (2009) The food-print of Paris: long-term reconstruction of the nitrogen flows imported into the city from its rural hinterland. Reg Environ Change 9:13-24

Boissiere J (1990) La consommation parisienne de bois et les sidérurgies périphériques: essai de mis en parallèle (milieu XVemilieu XIXe siècle.). In: Woronoff D (dir.) Forges et Forêts. Ed. de l'Ecole des Hautes Etudes en Sciences sociales, Paris

Bonnet A (1874) Annales des octrois, complément du 'Manuel de l'employé de l'octroi': Tomme premier. Llibrairie Bonnet, Paris

Boyden S, Newcombe K, Millar S, O'neil B (1981) The ecology of a city and its people: the case of Hong Kong. Australian National University Press, Canberra

Caron F (1997) Histoire des chemins de fer en France, Tome premier. 1740-1883. Fayard, Paris

Caron F (dir) (1990) Paris et ses réseaux: naissance d'un mode de vie urbain, XIXe-XXe siècles. Paris, Bibliothèque historique de la ville de Paris, Université de Paris IV: Paris-Sorbonne-Centre de recherche en l'histoire de l'innovation

Central Intelligence Agency (CIA) (2010) World Factbook, Washington, on the web, 14 Oct 2010. https://www.cia.gov/library/ publications/the-world-factbook/

Chaline C, Dubois-Maury J (1983) Energie et urbanisme. PUF, Quesais-Je? Paris

Chatzimpiros P (2011) Les empreintes environnementales de l'approvisionnement alimentaire: Paris, ses viandes et lait, XIXèXXIè siècles. PhD thesis, Université Paris Est. 351 pp

Chevalier M (1832) "Observations sur les mines de Mons et sur les autres mines de charbon qui approvisionnent Paris", Annales des mines, Troisième Série, Tome II. Carilian-Goeury, Paris

Compte De Chabrol (1829) Recherches statistiques sur la Ville de Paris et le département de la Seine; Recueil de tableau dressés et réunis d'après les ordres de monsieur le Compte de Chabrol, conseiller d'Etat, Préfet du Département. L'impr. Royale, Paris

Conseil Regional De L'ile-de-France (1984) Le Schéma régional de l'énergie rapport d'étape, Annexe au rapport No 07-84. Jan. N. p

D'Avenel G (1919) L'évolution des moyens de transport (voyageurs. lettres. marchandises). Flammarion, Paris

Daumas M (dir.) (1976) Evolution géographique industrielle de Paris et sa proche banlieue au XIXe siècle, vol II, Vers la maturité de l'industrie parisienne 1872-1914. Centre de Documentation d'Histoire des Techniques, Conservatoire des Arts et Métiers, (2 tomes) Paris 
De Saint-Julien A, Bienaymé G (1887) Histoire des droits d'entrée \& d'octroià Paris. Paul Dupont, Paris

Direction Generale De L'energie Et Des Matieres Premieres (DGEMP) (2007) Energies \& Matières premières: Statistiques 2006 de l'industrie gazière en France. Observatoire de l'Energie. Décembre, $23 \mathrm{p}$

Dutens J (1829) Histoire de la navigation intérieure de la France: avec une exposition des canaux à entreprendre pour en compléter le système, Volume 2. Sautelet/Bruxelles, Librairie Parisienne Française et Etrangère, Paris

Duvigneaud P (1980) La synthèse écologique. Populations, communautés, écosystèmes, biosphère, noosphère, 2e ed. [1st ed. 1974]. Doin, Paris

Eurostat (2008) Statistical books yearly statistics 2006. Office for Official Publications of the European Communities, Luxembourg

Fischer-Kowalski M, Haberl H (eds) (2007) Socioecological transitions and global change: trajectories of social metabolism and land use. (coll. Advances in Ecological Economics). Edward Elgar Publishing, Cheltenham/Northampton

Fischer-Kowalski M, Hüttler W (1998) Society's metabolism. The intellectual history of material flow analysis, part II: 1970-1998. J Ind Ecol 2(4):107-136

Giljum S, Lutz C, Jungnitz A (2007) A multi-regional environmental input-output model to quantify embodied material flows. 16th International input-output conference of the International InputOutput Association (IIOA), Istanbul, Turkey, on the web, 30 Sept 2010. http://www.iioa.org/Conference/16th-downable $\% 20$ paper.html

Goubert JP (ed) (1988) Du luxe au confort. Belin, Paris

Guillerme A (1991) Réseau: Genèse d'une catégorie dans la pensée de l'ingénieur sous la Restauration. Flux 7(6):5-17

Guillerme A (1992) Chaleur et confort, L'introduction du confort à Paris sous la Restauration. Hist Technol 14:16-53

Guillerme A (2007) La naissance de l'industrie à Paris: entre sueurs et vapeurs, 1780-1830. Editions Champ Vallon, Paris

Haberl H (2001) The energetic metabolism of societies, part I: accounting concepts. J Ind Ecol 5(1):11-33

Haberl H, et al. (2006) From LTER to LTSER: conceptualizing the socioeconomic dimension of long-term socioecological research. Ecol Soc 11(2):13, on the web 12 July 2011. http://www. ecologyandsociety.org/vol11/iss2/art13/

Hubacek K, Giljum S (2002) Applying physical input-output analysis to estimate land appropriation (ecological footprints) of international trade activities. Ecol Econom 44:137-151

Institut National de la Statistique et des Etudes Economiques (INSEE) (1966a) Annuaire statistique de la France 1966. Résumé rétrospectif, vol 72. Nouvelle série no 14. Paris, Imprimerie nationale: Presses universitaires de France

Institut National de la Statistique et des Etudes Economiques INSEE (1966b) Bulletin statistique de la région parisienne. Direction de la région parisienne. INSEE, Paris

International Energy Agency (IEA) (2008) Energy balances of OECD countries, 2008 Edn. Paris

Jacqmin F (1868) Chemins de fer, Leçon faites en 1867 à l'Ecole Impériale des Ponts et Chaussées par F. Jacqmin. Garnier Frères, Paris

Jacqmin F (1878) Commission centrale des chemins de fer- souscommission des tarifs. Réponses au questionnaire. Première partie. Imprimerie Nationale, Paris

Kennedy C, Cuddihy J, Engel-Yan J (2007) The changing metabolism of cities. J Ind Ecol 11(2):43-59

Kim E, Barles S (2010). The long term energetic metabolism of Paris (France): first quantitative results, 18th-20th century. Paper prepared for the 11th biennial conference of international society for ecological economics, Advancing sustainability in a time of crisis. Oldenburg/Bremen, 22-25 Aug
Krausmann F (2006) A city and its hinterland: the social metabolism of Vienna 1800-2000. Paper prepared for the 4th international round-table on urban environmental history of the 19th and 20th century. Paris, 16-18 November. N. p. (draft)

Krausmann F, Haberl H (2002) The process of industrialization from the perspective of energetic metabolism. Socioeconomic energy flows in Austria 1830-1995. Ecol Econom 41(2):177-201

Krausmann F, Haberl H, Erb K-H, Wackernagel M (2004) Resource flows and land use in Austria 1950-2000: using the MEFA framework to monitor society-nature interaction for sustainability. Land Use Policy 21:215-230

Larroque D (1997) Histoire du service de la production thermique d'électricité de France, Tome premier 1946-1973. Association pour l'histoire de l'Electricité en France. Paris, CompéditBeauregard

Macneill JR (2001) Something new under the sun. W.W. Norton \& Company, New-York

Malegarie C (1947) L'Electricité à Paris. Ch. Béranger (impr. de R. Hermieu), Paris/Liége

Matthews E et al (2000) The weight of nations: material outflows from industrial economies. World Resources Institute, Washington, DC

Melosi MV (2000) The sanitary city: urban infrastructure in America from colonial times to the present. The Johns Hopkins University Press, Baltimore/London

MIMAUSA (2010) (Mémoire et Impact des Mines d'urAniUm: Synthèse et Archives). Database of uranium mining activity in mainland France from Institut de Radioprotection et de Sureté Nucléaire (IRSN), on the web, 30 Sept 2010. http://mimaubdd. irsn.fr/Mimausa/

Minard CJ (1858-1861). Carte Figurative et approximative des tonnages de marchandises qui ont circulé en 1858—en 1859-en 1860 sur les voies d'eau et de fer de l'Empire Française. Champs-sur-Marne, ENPC 4.3563

Musset R (1959) Le pétrole dans la Basse-Seine. Ann Géogr 68(369):409-423

Musset R (1962) Le pipe-line du Havre à Paris: son trafic, son doublement. Ann Géogr 71(385):325

Observations sur L'approvisionnement de Paris en combustible (1816) Imp. de Dondey-Dupré, Paris

Peclet E (1844) Traité de la chaleur, considérée dans ses applications, $3^{\mathrm{e}}$ edn. D. Avanzo et Ce Editeur, Liège

PEGASE (2010) (Pétrole, Électricité, Gaz et Autres Statistiques de l'Énergie). Energy database from Ministère de l'Ecologie du Développement Durable, des Transport et du Logement (MEDDTL). Service de l'observation et des statistiques (SOeS). Paris, on the web, 20 Jan 2010. http://www.statistiques. developpement-durable.gouv.fr/donnees-ligne/telechargement/ pegase.html

Peyret H, Courau R (1935) Le pétrole et son économie. La Librairie Technique et Economique, Paris

Pinon P (2001) Un canal... Des Canaux, Exposition présentée à Paris du 7 mars au 8 juin 1986 dans le cadre de la Conciergerie. Caisse Nationale des Momuments Historiques et des Sites/Ministère de la Culture. Paris, Picard

Przybyla F (2007) Le blé, le sucre et le charbon: les parlementaires du Nord et leur action, 1881-1889. Villeneuve d'Ascq, Presses Univ. Septentrion

Renouard D (1960) Les transports de marchandises par fer, route et eau depuis 1850 (Coll. Recherches sur l'Economie française, no 2.). Armand Colin \& Fondation Nationale des Sciences Politiques, Paris

Reze C (2002) Les aménagements du réseau hydrographique du Morvan pour le flottage du bois, du XVIe au XVIIIe siècle. Mémoire de maîtrise d'archéologie, Université Paris I-PanthéonSorbonne, $61 \mathrm{p}$ 
Schandl H, Schulz NB (2002) Changes in United Kingdom's natural relations in terms of society's metabolism and land use from 1850 to the present day. Ecol Econom 41(2):203-221

Sieferle RP (2001) The subterranean forest. Energy systems and the industrial revolution. The White Horse Press, Cambridge

SITRAM (Système d'Information sur les TRAnsports de Marchandises), Database from French Transport Ministry (2006)

Smil V (2008) Energy in nature and society: general energetics of complex systems. The MIT Press, Cambridge

Societe des transports petroliers par pipe-line (TRAPIL) (1963) Pipeline Le Havre-Paris. Impr. Keller, Paris

Societe des transports petroliers par pipe-line (TRAPIL) (1972) Réseau de pipelines Le Havre-Paris. Impr. Keller, Paris

Sougy N, Verley P (2008) La première industrialisation: 1750-1880. Documentation Française no 8061. Jan.-fév. 63 p

Tarr JA, Dupuy G (eds) (1988) Technology and the rise of the networked city in Europe and America. Temple University Press, Philadelphie

Touzery M (1995) Atlas de la Généralité de Paris au XVIIIe siècle: un paysage retrouvé. Comité pour l'histoire économique et financière de la France. Impr. Nationale, Paris

United Nations (UN) (1982) Concepts and methods in energy statistics, with special reference to energy accounts and balances-a technical report. Department of International economic and social affaires, Technical Reports, Series F. No 29. United Nations, New-York, 138 p, on the web, 20 Feb 2009. http://og.ssb.no/ogwebpage/oldmanuals/SeriesF_29E.pdf
United Nations (UN) (1987) Energy statistics definitions units of measure and conversion factors. Department of International economic and social affaires, Technical Reports, Series F. No 44. United Nations, New-York, 74 p, (French version) on the web, 5 April 2009. http://og.ssb.no/ogwebpage/oldmanuals/SeriesF_ 44E.pdf

Van Den Bergh J, Verbruggen H (1999) Spatial sustainability, trade and indicators: an evaluation of the 'ecological footprint'. Ecol Econom 29:61-72

Voies navigables de france (VNF) (2007) Voie Navigable d'EuropeEdition 2007 (cartes). Direction de la Communication, Béthune, 1 p, on the web, 5 Jan 2009. http://www.vnf.fr

Weisz H, Krausmann F, Amann C, Eisenmenger N, Erb K-H, Hubacek K, Fischer-Kowalski M (2006) The physical economy of the European Union: cross-country comparison and determinants of material consumption. Ecol Econom 58:676-698

Wiedmann T (2008) A first empirical comparison of energy footprints embodied in trade-MRIO versus PLUM. Ecol Econom 68(7):1975-1990

Williot J-P (1999) Naissance d'un service public, Le gaz à Paris. Institut d'Histoire de l'Industrie. Editions Rive Droite, Paris

Wolman A (1965) The metabolism of cities. Sci Am 213:178-190

Woronoff D (1998) Histoire de l'industrie en France: du XVIe siècle à nos jours. Seuil, Paris 